Article

\title{
Diorganotin(IV) Derivatives of $N$-Methyl $p$-Fluorobenzo- Hydroxamic Acid: Preparation, Spectral Characterization, X-ray Diffraction Studies and Antitumor Activity
}

\author{
Naqeebullah ${ }^{1,2}$, Yang Farina ${ }^{1, *}$, Kok Meng Chan ${ }^{3}$, Lo Kong Mun ${ }^{4}$, Nor Fadilah Rajab ${ }^{5}$ and \\ Theng Choon Ooi ${ }^{5}$
}

1 School of Chemical Sciences and Food Technology, Faculty of Science \& Technology, Universiti Kebangsaan Malaysia, 43600 Bangi, Selangor Darul Ehsan, Malaysia

2 Department of Chemistry, Faculty of Basic Sciences, University of Balochistan, 87300 Sariab Road Quetta, Pakistan

3 Environmental Health Programme, Faculty of Allied Health Sciences, Universiti Kebangsaan Malaysia, Jalan Raja Muda Abdul Aziz, 50300 Kuala Lumpur, Malaysia

4 Department of Chemistry, Faculty of Science, University of Malaya, 50603 Kuala Lumpur, Malaysia

5 Biomedical Science Programme, Faculty of Health Sciences, Universiti Kebangsaan Malaysia, Jalan Raja Muda Abdul Aziz, 50300 Kuala Lumpur, Malaysia

* Author to whom correspondence should be addressed; E-Mail: farina@ukm.my; Tel.: +601-3388-5492; Fax: +603-8921-5410.

Received: 23 May 2013; in revised form: 15 July 2013 / Accepted: 16 July 2013 /

Published: 22 July 2013

\begin{abstract}
Three diorganotin(IV) complexes of the general formula $R_{2} \operatorname{Sn}[R c C(O) N(R \mathrm{~N}) \mathrm{O}]$ $(R \mathrm{c}=$ aryl, $R \mathrm{~N}=$ Alkyl) have been synthesized by refluxing in toluene the corresponding diorganotin(IV) oxides with the free ligand $N$-methyl $p$-fluorobenzohydroxamic acid, using a Dean and Stark water separator. The ligand was derived from the reaction of the corresponding $p$-fluorobenzoyl chloride and $N$-methylhydroxylamine hydrochloride in the presence of sodium hydrogen carbonate. The isolated free ligand and its respective diorganotin compounds have been characterized by elemental analysis, IR and ${ }^{1} \mathrm{H}-,{ }^{13} \mathrm{C}$-, ${ }^{119} \mathrm{Sn}-\mathrm{NMR}$ spectroscopies. The crystal structures of the diorganotin complexes have been confirmed by single crystal X-ray diffraction methods. The investigations carried out on the diorganotin(IV) complexes of $N$-methyl $p$-fluorobenzohydroxamic acid confirmed a 1:2 stoichiometry. The complex formation took place through the $O, O$-coordination via the carbonyl oxygen and subsequent deprotonated hydroxyl group to the tin atom. The crystal
\end{abstract}


structures of three diorganotin complexes were determined and were found to adopt six coordination geometries at the tin centre with coordination to two ligand moieties.

Keywords: organotin; hydroxamic acid; X-ray diffraction; antitumor activity

\section{Introduction}

Hydroxamic acids [1], $R \mathrm{cC}(\mathrm{O}) \mathrm{N}(R \mathrm{~N}) \mathrm{OH}(R \mathrm{c}=$ alkyl/aryl; $R \mathrm{~N}=$ alkyl/aryl or $\mathrm{H})$, have been the source of much biochemical interest in recent years reflecting the fact that they demonstrate a wide variety of biological activities. Much of their activities are due to their chelating properties with metal ions, especially with transition metals, hence constituting a very important class of chelating agents with versatile biological activities [2,3]. The principal coordination mode observed in metal-hydroxamic acid complexes is the $O, O$-bidentate chelation in which the ligand is either singly deprotonated (hydroxamato) or doubly $(R \mathrm{~N}=\mathrm{H})$ deprotonated (hydroximato) [4]. A number of synthetic routes are available for the preparation of hydroxamic acids [5-10], but some of them are tedious, time consuming and also costly. The reasonable way of producing hydroxamic acid derivative is the reaction of hydroxylamine with acid chlorides or esters [11]. Hydroxamic acids are capable of the inhibition of a variety of enzymes, including ureases [12,13], peroxidases [14], and matrix metalloproteinases (MMP) [15,16] and are also capable of competing as siderophores for iron-(III) [17,18]. These compounds are used in the design of therapeutics targeting cancer [19,20], cardiovascular diseases [21], HIV [22], Alzheimer's [23], malaria [24,25], and allergic diseases [26].

Organotin(IV) complexes with bidentate O-donor ligands [27], including $N$-substituted hydroxamic acids, are well known and have been a continuing subject of study in the recent years [28], highlighting the synthesis of a number of complexes with interesting properties [29-31]. Moreover, some of the diorganotin(IV) hydroxamates have been structurally characterized by X-ray diffraction studies, which are well documented in the literature [32-34]. Organotin compounds are widely studied class of organometallic compounds with, broad spectrum of applications, being used in antifouling paints [35], as homogeneous catalysts [36] and in agriculture that give rise to ubiquitous environmental contamination [37,38]. The biological activity of organotin compounds is predominantly determined by the number and nature of organic groups linked to the central tin atom and generally decreases in the following order: $\mathrm{R}_{3} \mathrm{Sn}^{+}>\mathrm{R}_{2} \mathrm{Sn}^{2+}>\mathrm{RSn}^{3+}$ [29,39-41]. In addition, the increasing interest in the chemistry of organotin(IV) compounds has led to the extended studies against cancer $[42,43]$.

The structural and biological diversity of organotin hydroxamates stirred our interest to further illustrate the coordination chemistry and anti-proliferative activity of organotin compounds with hydroxamic acid, herein we report the synthesis of a new ligand $N$-methyl $p$-fluorobenzohydroxamic acid $\left(\mathrm{L}_{\mathrm{H}}\right)$ and its diorganotin(IV) derivatives $\left(\mathrm{CH}_{3}\right)_{2} \mathrm{SnL}_{2},\left(\mathrm{C}_{4} \mathrm{H}_{9}\right)_{2} \mathrm{SnL}_{2}$ and $\left(\mathrm{C}_{6} \mathrm{H}_{5}\right)_{2} \mathrm{SnL}_{2}$ with interesting structural features to expand their scope. 


\section{Results and Discussion}

\subsection{Synthesis}

The ligand was prepared by the reaction of $p$-fluorobenzoyl chloride with $N$-methyl-hydroxylamine hydrochloride in the presence of sodium hydrogen carbonate as catalyst. All the reagents were in the same ratio by weight (i). Diorganotin(IV) complexes were synthesized in 2:1 molar ratio, by refluxing the free ligand with diorganotin(IV) oxides in hot toluene for 5-6 $\mathrm{h}$ with stirring and the water formed was removed azeotropically using a Dean-Stark apparatus (ii), as summarized in Scheme 1. The resulting solution was cooled and filtered and the solvent evaporated. The solid was precipitated by adding petroleum ether $\left(60-80^{\circ} \mathrm{C}\right)$ and then recrystallized from ethanol. The purity of the ligand and the diorganotin complexes were assured by TLC analysis using silica gel-G as adsorbent.

Scheme 1. A general reaction scheme of the free ligand (i) and its diorganotin(IV) complexes (ii).<smiles>O=C(Cl)c1ccc(F)cc1</smiles><smiles>CN(O)C(=O)c1ccc(F)cc1</smiles>

$N$-methyl $p$-fluorobenzohydroxamic acid (i)

$+$

$\mathrm{R}_{2} \mathrm{SnO}$

Toluene

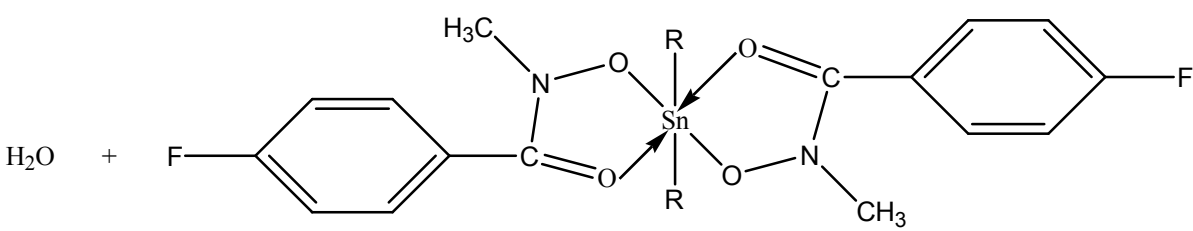

(ii)

$\mathrm{R}=\mathrm{CH}_{3}, \mathrm{C}_{4} \mathrm{H}_{9}$ and $\mathrm{C}_{6} \mathrm{H}_{5}$

The newly synthesized ligand and its diorganotin complexes are white or colorless solids, stable in air and soluble in common organic solvents. Tin was determined gravimetrically, by igniting a known quantity of each complex. The calculated values were in a good agreement with the experimental values.

\subsection{Infra-Red Spectroscopy}

Solid state infrared spectra of the $N$-methyl $p$-fluorobenzohydroxamic acid and its complexes have been recorded in the range $4,000-400 \mathrm{~cm}^{-1}$. The principal infrared absorption bands are those due to $v(\mathrm{O}-\mathrm{H}), v(\mathrm{C}=\mathrm{O}), v(\mathrm{C}-\mathrm{N})$ and $v(\mathrm{~N}-\mathrm{O})$ stretching vibrations of the hydroxamate group observed in the 
spectrum of free hydroxamic acid at 3,175, 1,610, 1,432 and 908 respectively. The $v(\mathrm{O}-\mathrm{H})$ band is observed in the range $3,175 \mathrm{~cm}^{-1}$ appeared as a broad band indicating the presence of extensive hydrogen bonding. The characteristic band $v(\mathrm{C}=\mathrm{O})$ positioned within the range $1,610 \mathrm{~cm}^{-1}$ is notably, below the usual ketonic $v(\mathrm{C}=\mathrm{O})$ range of $1,650 \mathrm{~cm}^{-1}[44,45]$, indicates that in the solid state the ligand exist in the keto form.

The IR spectra of the free ligand and its diorganotin(IV) complexes illustrated clear differences. In all cases, $(\mathrm{O}-\mathrm{H})$ stretching modes were absent in the spectra of the complexes, thus suggesting the deprotonation of the hydroxamate group on complexation, Similarly, the $(\mathrm{C}=\mathrm{O})$ group are shifted to lower frequencies in the range $1,599-1,602 \mathrm{~cm}^{-1}$, indicating a further shift of $(C=O)$ to lower energy thus suggesting the predominance of the enolic form to give a five membered chelate rings at the tin centre. Moreover, the (N-O) stretching vibrations occurring at $938-948 \mathrm{~cm}^{-1}$ in the diorganotin(IV) hydroxamates, are shifted to higher frequencies, excluding the coordination via the nitrogen atom [46]. The occurrence of $(\mathrm{Sn}-\mathrm{O})$ in the range of $474-453 \mathrm{~cm}^{-1}$ indicates the chelation of the tin centre to the enolate oxygen $[45,47]$.

\subsection{NMR Spectroscopy}

${ }^{1} \mathrm{H}-\mathrm{NMR}$ spectra for the investigated ligand and their organotin(IV) complexes have been recorded in $\mathrm{CDCl}_{3}$ solution and tetramethylsilane as internal standard at room temperature. In the ${ }^{1} \mathrm{H}-\mathrm{NMR}$ spectra the free ligand show a signal at $10.34 \mathrm{ppm}$, which is due to the intramolecularly hydrogen bonded hydroxyl proton. The peak disappeared in the ${ }^{1} \mathrm{H}-\mathrm{NMR}$ spectra of the complexes indicating, thereby, the substitution of the hydroxyl proton and chelation of the oxygen to the tin atom. The proton signals appearing in the region $3.40 \mathrm{ppm}$ were attributed to methyl protons attached to the nitrogen atom, which remained unchanged on chelation, supporting further, the non-involvement of this group in complexation. In the dimethyltin(IV) derivative, the proton resonances appeared as a singlet in the region $0.713 \mathrm{ppm}$, with well-defined satellites. The value of the two bond coupling constant ${ }^{2} J\left({ }^{119} \mathrm{Sn}-{ }^{1} \mathrm{H}\right)$ calculated from tin satellites in the ${ }^{1} \mathrm{H}-\mathrm{NMR}$ spectra of dimethyltin(IV) complex was found in the region of $84.22 \mathrm{~Hz}$, and the estimated $\mathrm{C}-\mathrm{Sn}-\mathrm{C}$ bond angle is $136.4^{\circ}$, based on the equation of Lockhart and Manders [Equation (1)] [48], which fall in the region for six-coordinate tin [49]. In the dibutyltin(IV) complex, the butyl protons were found as a multiplet and a triplet in the regions $1.36-1.84 \mathrm{ppm}$ and $0.88 \mathrm{ppm}$ due to $-\left(\mathrm{CH}_{2}\right)_{3}$ and the terminal $\mathrm{CH}_{3}$ respectively. A complex multiplet found at 8.17-8.32 ppm for the aromatic protons of the free ligand and all complexes, is due to the overlapping of the signals of the aromatic protons of the ligand and phenyl group protons in diphenyltin(IV) complex [50,51].

$$
\theta(\mathrm{C}-\mathrm{Sn}-\mathrm{C})=0.0161\left({ }^{2} J_{\mathrm{Sn}-\mathrm{H}}\right)^{2}-1.32\left({ }^{2} J_{\mathrm{Sn}-\mathrm{H}}\right)+133.4
$$

${ }^{13} \mathrm{C}-\mathrm{NMR}$ spectra for the investigated ligand and its organotin(IV) complexes have been recorded in $\mathrm{CDCl}_{3}$ solution and tetramethylsilane as internal standard at room temperature. ${ }^{13} \mathrm{C}-\mathrm{NMR}$ chemical shifts in every complex showed the expected resonances with appropriate multiplicities and intensities and the spectra are generally in agreement with the results drawn from ${ }^{1} \mathrm{H}-\mathrm{NMR}$ signals. The carbonyl $(\mathrm{C}=\mathrm{O})$ signal appeared at $165.0 \mathrm{ppm}$ in free ligand and were shifted upfield in the corresponding complexes (164.9-161.3ppm), indicating a decrease in electron density at the carbon atom when oxygen atom is chelated to the tin atom. The methyl carbon attached to the nitrogen appears at 
38.37-40.98 ppm. In dimethyltin (IV) complex, the methyl carbon attached to the tin appeared at $6.57 \mathrm{ppm}$ and the observed ${ }^{119} \mathrm{Sn}$ satellites in ${ }^{13} \mathrm{C}-\mathrm{NMR}$ spectrum provide ${ }^{1} J\left({ }^{13} \mathrm{C}-{ }^{119} \mathrm{Sn}\right)$ coupling constant value $785.27 \mathrm{~Hz}$, and the estimated C-Sn-C bond angle is $145.7^{\circ}$, based on the equation of Lockhart and Manders [Equation (2)] [48], which is of the same order of magnitude of those observed in hexa-coordinate organotin(IV) compounds. The butyl carbons attached to the tin in dibutyltin(IV) complex appeared at 13.85, 26.63, 26.85 and $27.44 \mathrm{ppm}$. The signals appeared at 115-163 ppm, were assigned to the aromatic carbons. By comparing the ${ }^{13} \mathrm{C}$-NMR spectra of the free ligand with its diorganotin (IV) complexes, a slight upfield shift has been observed in the position of carbonyl signal, suggesting the bidentate nature of hydroxamate group. One can notice that the oxygen chelated to metal ion reduce the electron density at carbon atom, hence considered the cause for chemical shift [52,53].

$$
\left({ }^{1} J_{\text {Sn-C }}\right)=11.4 \theta-875
$$

The ${ }^{119} \mathrm{Sn}-\mathrm{NMR}$ spectra of diorganotin(IV) complexes studied herein in DMSO, at room temperature. The ${ }^{119}$ Sn-NMR chemical shifts of organotin(IV) compounds appear to depend not only on the coordination number, on the other hand also on the alkyl groups bound to the metal ion and the types of donor atoms [54]. The spectra show one sharp signal in dimethyl-, dibutyl- and diphenyltin complexes at $\delta=-407 \mathrm{ppm},-367 \mathrm{ppm}$ and $-205 \mathrm{ppm}$ respectively, which strongly supports the six coordination around tin in a distorted octahedral geometry [55-57]. In the later an associated structure such as the stereoisomers specie is thus present in solution similar to spectra have reported by $[56,58]$.

\subsection{X-ray Crystallography}

The crystal structure of compound (1), (2) and (3) are shown in Figures 1-3, respectively. Selected bond angles and bond lengths are presented in Tables 1 and 2. The molecular structures of these diorganotin complexes showed that the tin atom is bonded to two $N$-methyl-p-fluorobenzohydroxamic acids via the hydroxyl oxygen and the carbonyl oxygen [30,59]. The two organic groups of the diorganotin fragment complete the six coordination geometry at tin for the three complexes. It is evident that the carbonyl oxygen are weakly coordinated to the tin compared to the covalent Sn-O $\mathrm{O}_{\text {hydroxyl }}$ bonds [compound (1): Sn-O1 2.0921(9), 2.0921(9) and Sn-O2 2.3778(9), 2.3778(9); compound (2): Sn-O1: 2.117(3), 2.132(3) and Sn-O2 2.356(3), 2.407(3); compound (3): Sn-O1 2.110(2), 2.103(2) and Sn-O2 2.221(2), 2.183(2)]. The bond distances and angles of the three complexes as given in Tables 1 and 2 revealed that the geometry of the crystals is distorted octahedral around the six coordinated tin(IV) ion, similar to the diphenyltin(IV) bis( $N$-methyl $p$-bromobenzohydroxamate) [27] and di- $n$-butyl-(4-chlorobenzo-hydroxamato)tin(IV) [60]. The distortion in the coordination sphere of the metal ion from the ideal geometry may be due to the structural constraints imposed by the hydroxamic acid ligand framework. The ligand bite angles $\mathrm{O} 1-\mathrm{Sn}-\mathrm{O} 2$ at tin for the three complexes are small with the values of $71.22(3)^{\circ}, 71.23(3)^{\circ}$ for $(1), 70.36(9)^{\circ}, 71.96(10)^{\circ}$ for $(2)$ and $73.26(8)^{\circ}$, $74.15(8)^{\circ}$ for (3). Interestingly, the two alkyl substituents of the diorganotin fragment in compounds (1) and (2) adopt the trans conformation [C-Sn-C angle of (1) and (2) is $143.98(8)^{\circ}$ and $141.2(2)^{\circ}$, respectively] whereas the two phenyl substituent in complex (3) adopts the cis conformation [C-Sn-C angle is $\left.104.2(1)^{\circ}\right]$. 
Figure 1. Thermal ellipsoidal plot of $\mathrm{C}_{18} \mathrm{H}_{20} \mathrm{~F}_{2} \mathrm{~N}_{2} \mathrm{O}_{4} \mathrm{Sn}$ (compound 1). Displacement ellipsoids are drawn at the $50 \%$ probability level, and $\mathrm{H}$ atoms are shown as spheres of arbitrary radii. Symmetry transformation code $\mathrm{i}:-\mathrm{x}+1, \mathrm{y},-\mathrm{z}+3 / 2$.

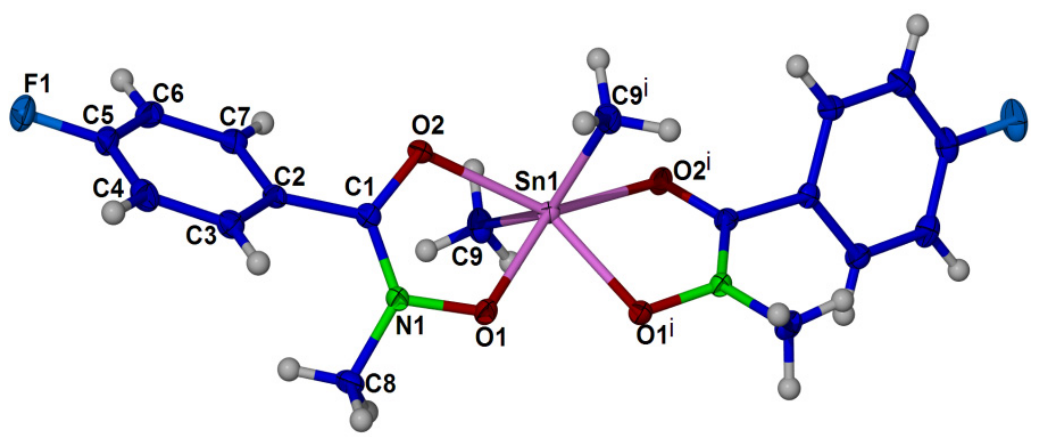

Figure 2. Thermal ellipsoidal plot of $\mathrm{C}_{24} \mathrm{H}_{32} \mathrm{~F}_{2} \mathrm{~N}_{2} \mathrm{O}_{4} \mathrm{Sn}$ (compound 2). Displacement ellipsoids are drawn at the $50 \%$ probability level, and $\mathrm{H}$ atoms are shown as spheres of arbitrary radii.

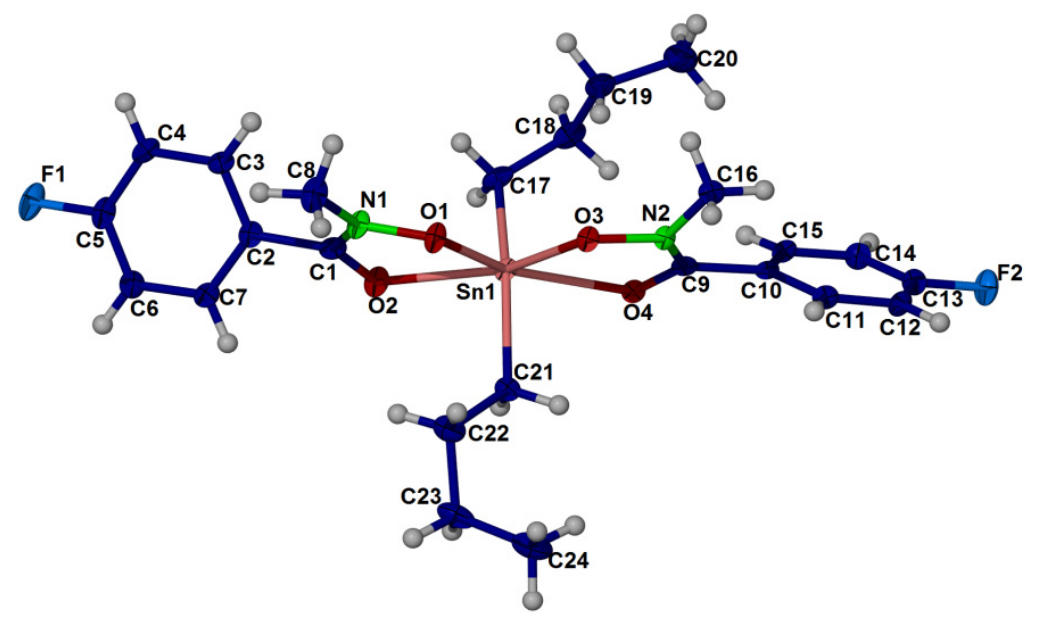

Figure 3. Thermal ellipsoidal plot of $\mathrm{C}_{28} \mathrm{H}_{24} \mathrm{~F}_{2} \mathrm{~N}_{2} \mathrm{O}_{4} \mathrm{Sn}$ (compound 3). Displacement ellipsoids are drawn at the $50 \%$ probability level, and $\mathrm{H}$ atoms are shown as spheres of arbitrary radii.

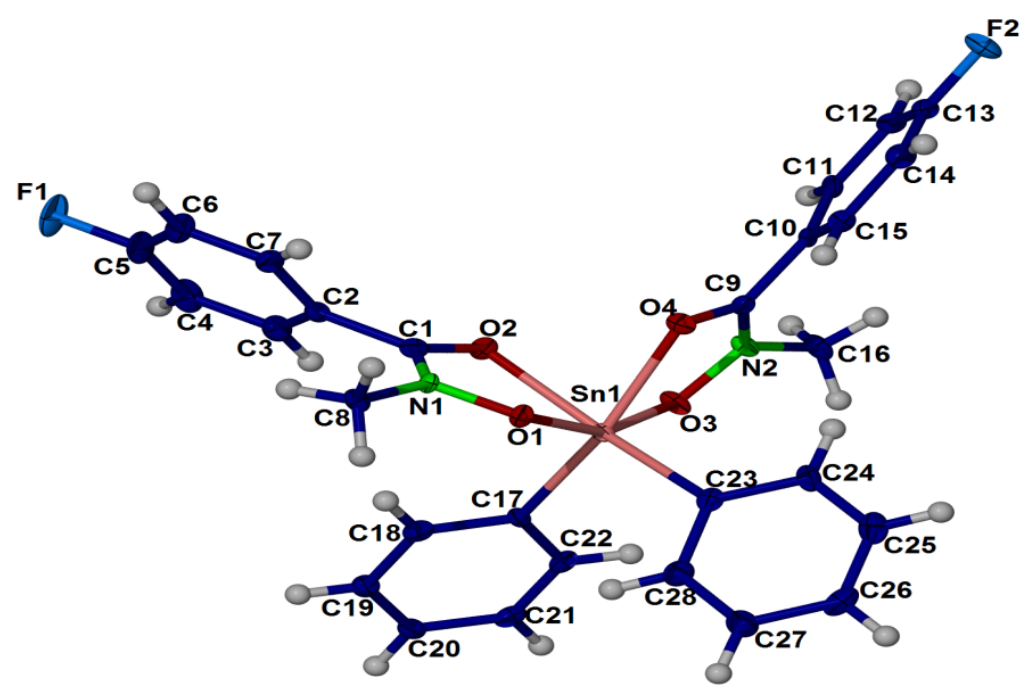


Table 1. Selected bond lengths (A) of the complexes (1), (2) and (3).

\begin{tabular}{|c|c|c|c|c|c|c|c|c|c|c|c|}
\hline \multicolumn{4}{|c|}{ (1) } & \multicolumn{4}{|c|}{ (2) } & \multicolumn{4}{|c|}{ (3) } \\
\hline Sn1-O1 & $2.0921(9)$ & F1-C5 & $1.3583(15)$ & Sn1 O1 & $2.117(3)$ & $\mathrm{N} 1 \mathrm{C} 1$ & $1.312(5)$ & $\mathrm{Sn} 1 \mathrm{O} 3$ & $2.103(2)$ & $\mathrm{N} 1 \mathrm{C} 1$ & $1.326(4)$ \\
\hline Sn1-O1 i & $2.0921(9)$ & O1-N1 & $1.3807(13)$ & $\mathrm{Sn} 1 \mathrm{C} 21$ & $2.125(4)$ & N1 O1 & $1.385(4)$ & Sn1 O1 & $2.110(2)$ & N1 O1 & $1.379(3)$ \\
\hline Sn1-C9 i & $2.1184(13)$ & $\mathrm{O} 2-\mathrm{C} 1$ & $1.2696(15)$ & $\mathrm{Sn} 1 \mathrm{O} 3$ & $2.132(3)$ & N1 C8 & $1.453(5)$ & Sn1 C17 & $2.144(3)$ & N1 C8 & $1.452(4)$ \\
\hline Sn1-C9 & $2.1184(13)$ & $\mathrm{N} 1-\mathrm{C} 1$ & $1.3192(16)$ & Sn1 C17 & $2.143(4)$ & $\mathrm{N} 2 \mathrm{C} 9$ & $1.321(5)$ & $\mathrm{Sn} 1 \mathrm{C} 23$ & $2.156(3)$ & N2 C9 & $1.322(4)$ \\
\hline $\mathrm{Sn} 1-\mathrm{O} 2$ & $2.3778(9)$ & N1-C 8 & $1.4558(16)$ & $\mathrm{Sn} 1 \mathrm{O} 2$ & $2.356(3)$ & $\mathrm{N} 2 \mathrm{O} 3$ & $1.375(4)$ & Sn1 O4 & $2.183(2)$ & $\mathrm{N} 2 \mathrm{O} 3$ & $1.380(3)$ \\
\hline $\mathrm{Sn} 1-\mathrm{O} 2 \mathrm{i}$ & $2.3778(9)$ & & & Sn1 O4 & $2.407(3)$ & $\mathrm{O} 2 \mathrm{C} 1$ & $1.262(5)$ & $\mathrm{Sn} 1 \mathrm{O} 2$ & $2.221(2)$ & $\mathrm{O} 2 \mathrm{C} 1$ & $1.277(4)$ \\
\hline & & & & F1 C5 & $1.354(5)$ & $\mathrm{O} 4 \mathrm{C} 9$ & $1.263(5)$ & F1 C5 & $1.353(4)$ & O4 C9 & $1.285(4)$ \\
\hline
\end{tabular}

Table 2. Selected bond angles (deg) of the complexes (1), (2) and (3).

\begin{tabular}{|c|c|c|c|c|c|c|c|c|}
\hline \multicolumn{4}{|c|}{ (1) } & \multicolumn{3}{|c|}{$(2)$} & \multicolumn{2}{|c|}{ (3) } \\
\hline O1-Sn1-O1i & $76.58(5)$ & C9i-Sn1-O2i & i $82.95(4)$ & O1 Sn1 C21 & $105.01(13)$ & C9 N2 O3 & O3 Sn1 O1 158.08(9) & $\mathrm{C} 9 \mathrm{~N} 2 \mathrm{O} 3$ \\
\hline O1-Sn1-C9i & $97.86(5)$ & C9-Sn1-O2i & $85.64(4)$ & O1 Sn1 O3 & $76.51(10)$ & O3 N2 C16 111.9(3) & O3 Sn1 C17 89.96(10) & O1 N1 C8 $112.8(2)$ \\
\hline O1i-Sn1-C9i & $110.40(5)$ & $\mathrm{O} 2-\mathrm{Sn} 1-\mathrm{O} 2 \mathrm{i}$ & i $142.49(4)$ & $\mathrm{C} 21 \mathrm{Sn} 1 \mathrm{O} 3$ & $103.19(13)$ & N1 O1 Sn1 $114.8(2)$ & O1 Sn1 C17 103.49(10) & O3 N2 C16 112.7(2) \\
\hline O1-Sn1-C9 & $110.40(5)$ & N1-O1-Sn1 & $113.09(7)$ & O1 Sn1 C17 & $104.85(14)$ & $\mathrm{C} 1 \mathrm{O} 2 \mathrm{Sn} 1 \quad 110.1(2)$ & O3 Sn1 C23 $105.08(10)$ & $\mathrm{C} 1 \mathrm{O} 2 \mathrm{Sn} 1 \quad 112.7(18)$ \\
\hline O1i-Sn1-C9 & $97.86(5)$ & C1-O2-Sn1 & $107.76(8)$ & $\mathrm{C} 21 \mathrm{Sn} 1 \mathrm{C} 17$ & $141.14(16)$ & C9 O4 Sn1 & O1 Sn1 C23 88.55(10) & N1 O1 Sn1 113.1(16) \\
\hline C9i-Sn1-C9 & $143.98(8)$ & C1-N1-O1 & $118.20(10)$ & O3 Sn1 C17 & $107.52(14)$ & N2 O3 Sn1 & C17 Sn1C23 104.16(11) & N2 O3 Sn1 113.1(16) \\
\hline O1-Sn1-O2 & $71.22(3)$ & C1-N1-C8 & $128.68(11)$ & O1 Sn1 O2 & $71.96(10)$ & C18 C17 Sn1 118.9(3) & O3 Sn1 O4 & C9 O4 Sn1 113.8(18) \\
\hline O1i-Sn1-O2 & $145.75(3)$ & O1-N1-C8 & $112.43(10)$ & C21 Sn1 O2 & $85.83(13)$ & Sn1 C17 H17A 107.6 & O1 Sn1 O4 & C22 C17 Sn1 120.5(2) \\
\hline C9i-Sn1-O2 & $85.64(4)$ & $\mathrm{O} 2-\mathrm{C} 1-\mathrm{N} 1$ & $120.10(12)$ & O3 Sn1 O2 & $148.46(10)$ & Sn1 C17 H17B 107.6 & C17 Sn1 O4 $159.85(10)$ & C18 C17 Sn1 122.0(2) \\
\hline C9-Sn1-O2 & $82.95(4)$ & $\mathrm{O} 2-\mathrm{C} 1-\mathrm{C} 2$ & 119.21(11) & $\mathrm{C} 17 \mathrm{Sn} 1 \mathrm{O} 2$ & $80.36(14)$ & C22 C21Sn1 117.2(3) & C23 Sn1 O4 92.10(10) & C24 C23 Sn1 126.3(2) \\
\hline O1-Sn1-O2i & $145.75(3)$ & $\mathrm{N} 1-\mathrm{C} 1-\mathrm{C} 2$ & $120.64(11)$ & O1 Sn1 O4 & $146.74(9)$ & Sn1 C21 H21A 108.0 & O3 Sn1 O2 90.35(8) & C28 C23 Sn1 116.7(2) \\
\hline \multirow[t]{6}{*}{$\mathrm{O} 1 \mathrm{i}-\mathrm{Sn} 1-\mathrm{O} 2 \mathrm{i}$} & $71.23(3)$ & F1-C5-C6 & $118.22(13)$ & C21 Sn1 O4 & $80.23(12)$ & Sn1 C21 H21B 108.0 & O1 Sn1 O2 & $\mathrm{O} 2 \mathrm{C} 1 \mathrm{~N} 1$ \\
\hline & & & & O3 Sn1 O4 & $70.36(9)$ & O2 C1 N1 121.1(4) & C17 Sn1 O2 87.69(10) & F1 C5 C6 \\
\hline & & & & C17 Sn1 O4 & $88.16(13)$ & F1 C5 C6 & C23 Sn1 O2 $160.33(10)$ & $\mathrm{F} 1 \mathrm{C} 5 \mathrm{C} 4$ \\
\hline & & & & O2 Sn1 O4 & $141.15(9)$ & F1 C5 C4 117.7(4) & O4 Sn1 O2 80.26(8) & O4 C9 N2 \\
\hline & & & & C1 N1 O1 & $118.8(3)$ & O4 C9 N2 $120.1(3)$ & C1 N1 O1 $117.6(2)$ & \\
\hline & & & & O1 N1 C8 & $111.7(3)$ & O4 C9 C10 119.2(3) & & \\
\hline
\end{tabular}




\subsection{Antitumor Activity in vitro}

The synthesized organotins were evaluated for the biological activity, specifically cytotoxicity on HCT116 colorectal carcinoma cell line. All the tested organotins induced a concentration-dependent anti-proliferative effect towards HCT116 cells upon treatment for $24 \mathrm{~h}$. However, the cytotoxicity of dibutyltin(IV)Bis[ $N$-methyl $p$-fluorobenzohydroxamate] could not be assessed due to the lack of solubility in DMSO at room temperature. Triphenyltin(IV) $N$-methyl $p$-fluorobenzohydroxamate was the most potent organotin with $\mathrm{IC}_{50}$ value of $0.41 \mu \mathrm{M}$, follow by diphenyltin(IV)bis[ $N$-methyl $p$-fluorobenzohydroxamate $]$ and dimethyltin(IV)bis[ $N$-methyl $p$-fluorobenzohydroxamate $]$ as shown in Table 3. Our current data are in agreement with previous study, whereby the triphenyltin(IV) complexes exhibit higher antiproliferative effects compare to diphenyltin(IV) complexes [61-63]. Similarily, it has also been demonstrated that triphenyltin(IV) complex possess the highest cytotoxic effect whereas the dimethyltin(IV) complex have little or no cytotoxic effect on HCT116 cells upto $250 \mu \mathrm{M}$ treatment for $24 \mathrm{~h}$ [64]. Therefore, triphenyltin(IV) $N$-methyl $p$-fluorobenzohydroxamate has the potential to be developed as an anti-tumor agent due to the potent cytotoxic effect at nano molar concentration which warrant further mechanistic studies.

Table 3. $\mathrm{IC}_{50}$ values of organotins on HCT116 cells.

\begin{tabular}{ll}
\hline Compounds & $\mathbf{I C}_{\mathbf{5 0}}$ values $(\boldsymbol{\mu M})$ \\
\hline dimethyltin(IV)bis[N-methyl $p$-fluorobenzohydroxamate $]$ & $>40$ \\
diphenyltin(IV)bis[N-methyl $p$-fluorobenzohydroxamate $]$ & 2.45 \\
dibutyltin(IV)bis[N-methyl $p$-fluorobenzohydroxamate] & $\mathrm{NA}$ \\
triphenyltin(IV) $N$-methyl $p$-fluorobenzohydroxamate & 0.41 \\
\hline
\end{tabular}

\section{Experimental}

\subsection{General}

The chemicals were purchased from Aldrich and were used as received. All the chemicals were of analytical grade. The triphenyltin(IV) $N$-methyl $p$-fluorobenzohydroxamate was success-fully prepared according to a standard method reported in the literature [65]. The melting points were determined in open capillary tubes using an Electrothermal 9300 digital melting point apparatus. The percentage compositions of the elements $(\mathrm{CHN})$ for the compounds were determined using an elemental analyzer CHNS-O Model Fison EA 1108. Solid state infrared spectra of the compounds are recorded in the range 4000-400 $\mathrm{cm}^{-1}$. The infrared spectra were recorded as potassium bromide discs using a Perkin-Elmer spectrophotometer GX. The ${ }^{1} \mathrm{H}-,{ }^{13} \mathrm{C}$ - and ${ }^{119}$ Sn-nuclear magnetic resonance spectra were recorded using the Bruker FT-NMR $600 \mathrm{MHz}$ Cryo-Prob spectrometer and the JEOL JNM-ECP 400 spectrometer using $\mathrm{DMSO} / \mathrm{CDCl}_{3}$ as a solvent and tetramethylsilane as an internal standard. Crystals structures determination were carried out on a Bruker Smart APEX CCD area detector diffractometer equipped with graphite mono-chromatised Mo-K $\alpha(\lambda=0.71073 \AA)$ radiation in each case. All data collection was carried out at $100 \mathrm{~K}$. The program APEX2 (Bruker [66]) was used for collecting frames of data, indexing of reflections and determination of lattice parameters, SAINT (Bruker 2008) for absorption correction, and SHELX97 (Sheldrick [67]). HCT116 human colorectal 
carcinoma cells were obtained from the American Type Culture Collection (Manassas, Virginia, USA). The cells were grown in McCoy's 5A medium (Invitrogen Cooperation, Paisley, UK) supplemented with 10\% FBS (PAA Laboratories, Morningside, QLD, Australia) and maintained at 37 ${ }^{\circ} \mathrm{C}$ with $5 \% \mathrm{CO}_{2}$ in humidified incubator.

\subsection{Synthesis of Ligand}

$p$-Fluorobenzoyl chloride $(0.01 \mathrm{~mol})$ was poured down drop by drop to a stirred cold solution of $N$-methylhydroxylamine hydrochloride $(0.01 \mathrm{~mol})$ containing sodium hydrogen carbonate $(0.01 \mathrm{~mol})$ and was further stirred for $30 \mathrm{~min}$ below $4{ }^{\circ} \mathrm{C}$. The solution was filtered and reduced to evaporate at low pressure. The precipitate was then dissolved in boiling ethyl acetate to remove any undissolved substance and then the filtrate is placed in the fridge overnight to obtain the crystals.

N-methyl p-fluorobenzohydroxamic acid. (HL): Colourless crystals. Yield: 84\%. Melting point: 88-89 ${ }^{\circ} \mathrm{C} .{ }^{1} \mathrm{H}-\mathrm{NMR}$ [DMSO-d 6 ]: $\delta(\mathrm{ppm})=10.34(\mathrm{~s}, \mathrm{br}, 1 \mathrm{H}, \mathrm{O}-\mathrm{H}), 7.11-7.57\left(\mathrm{~m}, 4 \mathrm{H}, \mathrm{C}_{6} \mathrm{H}_{4}\right), 3.40(\mathrm{~s}, 3 \mathrm{H}$, $\left.\mathrm{N}-\mathrm{CH}_{3}\right) .{ }^{13} \mathrm{C}-\mathrm{NMR}$ [DMSO-d 6 ]: $\delta(\mathrm{ppm})=165.0(\mathrm{CO}) ; 163-115(\mathrm{C}$ aromatic); 38.37 (C aliphatic). IR $\left(\mathrm{KBr}\right.$ pellets, $\left.\mathrm{cm}^{-1}\right):$ 3175(s, br, $\left.v \mathrm{O}-\mathrm{H}\right), 1610(\mathrm{~s}, v \mathrm{C}=\mathrm{O}), 1432(\mathrm{~s}, v \mathrm{C}-\mathrm{N})$ and $908(\mathrm{~s}, v \mathrm{~N}-\mathrm{O})$. Elemental Analysis: Calcd. (\%) for $\mathrm{H}_{8} \mathrm{C}_{8} \mathrm{NO}_{2} \mathrm{~F}$ (molecular weight: 169.06): C, 56.80; H, 8.28; N, 4.73. Found (\%): C, 57.08; H, 8.36; N, 5.14.

\subsection{Synthesis of Complexes}

Diorganotin(IV) complexes were synthesized by 2:1 molar ratio, dissolving the free ligand $(0.005 \mathrm{~mol})$ in hot toluene and then added the diorganotin(IV) oxides $(0.0025 \mathrm{~mol})$ to the solution. The solution was refluxed for 5-6 h with magnetic stirrer and the water formed during the course of reaction was removed azeotropically using a Dean-Stark apparatus. The solution was then cooled and filtered. The filtrate was placed under vacuum to evaporate the solvent and the solid was precipitated by adding petroleum ether $\left(60-80^{\circ} \mathrm{C}\right)$ and then recrystallized in ethanol.

Dimethyltin(IV)Bis[N-methyl p-fluorobenzohydroxamate] (1). Colourless crystals. Yield: 71\%. Melting point: $115-116{ }^{\circ} \mathrm{C} .{ }^{1} \mathrm{H}-\mathrm{NMR}$ [DMSO-d 6 ]: $\delta(\mathrm{ppm})=7.11-7.77\left(\mathrm{~m}, 4 \mathrm{H}, \mathrm{C}_{6} \mathrm{H}_{4}\right), 3.41(\mathrm{~s}, 3 \mathrm{H}$, $\left.\mathrm{N}-\mathrm{CH}_{3}\right), 0.71\left(\mathrm{~s}, 3 \mathrm{H}, \mathrm{Sn}-\mathrm{CH}_{3}\right),{ }^{13} \mathrm{C}-\mathrm{NMR}$ [DMSO-d 6 ]: $\delta(\mathrm{ppm})=161.3(\mathrm{CO}), 124-131$ (C aromatic), 39.29 (N-C), 6.57 (Sn-C). ${ }^{119}$ Sn-NMR [DMSO-d 6 ]: $\delta(\mathrm{ppm})=-407$. IR (KBr pellets, $\left.\mathrm{cm}^{-1}\right): 1600(\mathrm{~s}, v$ $\mathrm{C}=\mathrm{O}), 1432(\mathrm{~s}, v \mathrm{C}-\mathrm{N}), 938(\mathrm{~s}, v \mathrm{~N}-\mathrm{O}), 439$ (s, v Sn-O) and 576 (s, v Sn-C). Elemental Analysis: Calcd. (\%) for $\mathrm{H}_{20} \mathrm{C}_{18} \mathrm{~N}_{2} \mathrm{O}_{4} \mathrm{~F}_{2} \mathrm{Sn}$ (molecular weight: 485.16): C, 44.53; H, 4.13; N, 5.77; Sn, 24.53. Found (\%): C, 43.74; H, 5.78; N, 5.00; Sn, 22.05.

Dibutyltin(IV)Bis[N-methyl p-fluorobenzohydroxamate] (2). Colourless crystals. Yield: 77\%. Melting point: $103-104^{\circ} \mathrm{C} .{ }^{1} \mathrm{H}-\mathrm{NMR}$ [DMSO-d 6 ]: $\delta(\mathrm{ppm})=7.11-7.44\left(\mathrm{~m}, 4 \mathrm{H}, \mathrm{C}_{6} \mathrm{H}_{4}\right), 3.45\left(\mathrm{~s}, 3 \mathrm{H}, \mathrm{N}-\mathrm{CH}_{3}\right)$, $1.36-1.84\left(\mathrm{~m}, 6 \mathrm{H}, \mathrm{Sn}-\mathrm{CH}_{2}-\mathrm{CH}_{2}-\mathrm{CH}_{2}\right), 0.88\left(\mathrm{t}, 3 \mathrm{H},-\mathrm{CH}_{3}\right) .{ }^{13} \mathrm{C}-\mathrm{NMR}$ [DMSO-d 6 ]: $\delta(\mathrm{ppm})=164.5$ (CO), 115-129 (C aromatic), 40.98 (N-C), 13.85-27.44 (Sn-C). ${ }^{119}$ Sn-NMR [DMSO-d 6 ]: $\delta$ (ppm) $=-367$. IR (KBr pellets, $\mathrm{cm}^{-1}$ ): 1600 (s, v C=O), 1530 (s, v C-N), 953 (s, v N-O), 474 (s, v Sn-O) and 562 (s, v Sn-C). Elemental Analysis: Calcd. (\%) for $\mathrm{H}_{32} \mathrm{C}_{24} \mathrm{~N}_{2} \mathrm{O}_{4} \mathrm{~F}_{2} \mathrm{Sn}$ (molecular weight: 569.26): C, 50.59; $\mathrm{H}$, 5.85; N, 4.92; Sn, 20.90. Found (\%): C, 50.16; H, 4.91; N, 5.85; Sn, 19.21. 
Diphenyltin(IV)Bis[N-methyl p-fluorobenzohydroxamate] (3). White crystals. Yield: 82\%. Melting point: $203-204{ }^{\circ} \mathrm{C} .{ }^{1} \mathrm{H}-\mathrm{NMR}$ [DMSO-d 6 ]: $\delta(\mathrm{ppm})=8.17-8.32\left(\mathrm{~m}, 9 \mathrm{H}, \mathrm{C}_{6} \mathrm{H}_{4}, \mathrm{C}_{6} \mathrm{H}_{5}\right), 3.46(\mathrm{~s}, 3 \mathrm{H}$, $\left.\mathrm{N}-\mathrm{CH}_{3}\right) .{ }^{13} \mathrm{C}-\mathrm{NMR}$ [DMSO-d 6 ]: $\delta(\mathrm{ppm})=164.9(\mathrm{C}=\mathrm{O}), 123-150(\mathrm{C}$ aromatic), $38.86(\mathrm{~N}-\mathrm{C})$. ${ }^{119} \mathrm{Sn}-\mathrm{NMR}$ [DMSO-d 6 ]: $\delta(\mathrm{ppm})=-205 . \mathrm{IR}\left(\mathrm{KBr}\right.$ pellets, $\left.\mathrm{cm}^{-1}\right): 1599(\mathrm{~s}, v \mathrm{C}=\mathrm{O}), 1454(\mathrm{~s}, v \mathrm{C}-\mathrm{N})$, 948 (s, v N-O), 453 (s, $v$ Sn-O) and 563 (s, v Sn-C). Elemental Analysis: Calcd. (\%) for $\mathrm{H}_{24} \mathrm{C}_{28} \mathrm{~N}_{2} \mathrm{O}_{4} \mathrm{~F}_{2} \mathrm{Sn}$ (molecular weight: 609.19): C, 55.16; H, 3.97; N, 4.60; Sn, 19.54. Found (\%): C, 55.64; H, 4.74; N, 4.02; Sn, 18.60.

\subsection{X-ray Crystallography}

The single crystals of dimethyltin, dibutyltin and diphenyltin complexes of $N$-methyl $p$-fluorobenzohydroxamic acid of suitable quality were each mounted on a fine glass capillary and aligned on the Bruker SMART APEX2 diffractometer, equipped with graphite monochromated Mo- $K \alpha$ radiation source $(\lambda=0.71073 \AA)$. The range of theta for data collections together with other crystallographic information are given in Table 4. All calculations were performed using the SHELXTL-97 package [68]. Crystallographic data for the compounds (1), (2) and (3) have been deposited with the Cambridge Crystallographic Data Centre, CCDC reference numbers (924068, 933217, 924061). This information may be obtained free of charge from: the Director, CCDC, 12 Union Road, Cambridge, CB2 1EZ, UK (fax: +44-1223-336033; e-mail:deposit@ccdc.cam.ac.uk; website: http://www.ccdc.cam.ac.uk).

Table 4. Crystallographic parameter for the diorganotin compounds (1), (2) and (3).

\begin{tabular}{|c|c|c|c|}
\hline Compound & (1) & $(2)$ & (3) \\
\hline Gross formula & $\mathrm{C}_{18} \mathrm{H}_{20} \mathrm{~F}_{2} \mathrm{~N}_{2} \mathrm{O}_{4} \mathrm{Sn}$ & $\mathrm{C}_{24} \mathrm{H}_{32} \mathrm{~F}_{2} \mathrm{~N}_{2} \mathrm{O}_{4} \mathrm{Sn}$ & $\mathrm{C}_{28} \mathrm{H}_{24} \mathrm{~F}_{2} \mathrm{~N}_{2} \mathrm{O}_{4} \mathrm{Sn}$ \\
\hline$M$ & 485.05 & 569.21 & 609.15 \\
\hline Crystal system, space group & Monoclinic, $C 2 / c$ & Triclinic, $P-1$ & Triclinic, $P-1$ \\
\hline Crystal shape & Block & Block & Block \\
\hline Colour & Colourless & Colourless & White \\
\hline$a, \AA$ & $21.7581(2)$ & $11.0271(7)$ & $8.8999(2)$ \\
\hline$b, \AA$ & $11.2694(1)$ & $11.1155(7)$ & $12.3601(3)$ \\
\hline$c, \AA$ & $7.8964(1)$ & $11.1404(7)$ & $12.4362(3)$ \\
\hline$\alpha, \operatorname{deg}$ & 90 & $75.948(3)$ & $109.600(1)$ \\
\hline$\beta, \operatorname{deg}$ & 94.357 & $82.636(3)$ & $99.770(1)$ \\
\hline$\gamma, \operatorname{deg}$ & 90 & $77.919(3)$ & $98.015(1)$ \\
\hline$V, \AA^{3}$ & $1930.58(3)$ & $1290.99(14)$ & $1241.34(5)$ \\
\hline$Z$ & 4 & 2 & 2 \\
\hline$d_{\mathcal{c}}, \mathrm{g} / \mathrm{cm}^{-3}$ & 1.669 & 1.464 & 1.37 \\
\hline $\mathrm{F}(000)$ & 968 & 580 & 612 \\
\hline $\mathrm{M}, \mathrm{mm}^{-1}$ & 1.368 & 1.035 & 1.083 \\
\hline$T, \mathrm{~K}$ & $100(2)$ & $100(2)$ & $100(2)$ \\
\hline Crystal size, mm & $0.24 \times 0.29 \times 0.35$ & $0.40 \times 0.15 \times 0.05$ & $0.10 \times 0.05 \times 0.05$ \\
\hline$T_{\min }$ & 0.6415 & 0.6824 & 0.8995 \\
\hline$T_{\max }$ & 0.7457 & 0.9501 & 0.9479 \\
\hline
\end{tabular}


Table 4. Cont.

\begin{tabular}{|c|c|c|c|}
\hline Compound & (1) & $(2)$ & (3) \\
\hline measured reflections & 8979 & 10517 & 10184 \\
\hline independent reflections & 2221 & 5056 & 4581 \\
\hline reflections with $\mathrm{I}>2 \mathrm{~s}(\mathrm{I})$ & 2191 & 4593 & 4231 \\
\hline$R_{\mathrm{int}}$ & 0.0114 & 0.1236 & 0.0219 \\
\hline$\theta_{\max }$ & 27.5 & 26 & 25.5 \\
\hline$\theta_{\min }$ & 1.88 & 1.89 & 1.79 \\
\hline Completeness to theta & 0.998 & 0.998 & 0.993 \\
\hline$h$ & -2828 & -1213 & -1010 \\
\hline$k$ & -1414 & -1313 & -1414 \\
\hline$l$ & -1010 & -1313 & -1515 \\
\hline$R\left[F^{2}>2 \mathrm{~s}\left(F^{2}\right)\right]$ & 0.0136 & 0.0539 & 0.0239 \\
\hline$w R\left(F^{2}\right)$ & 0.0367 & 0.1444 & 0.0654 \\
\hline$S$ & 1.146 & 1.096 & 1.19 \\
\hline reflections & 2221 & 5056 & 4581 \\
\hline parameters & 125 & 302 & 336 \\
\hline restraints & 0 & 0 & 0 \\
\hline$\rho_{\max }$ e $\AA^{-3}$ & 0.261 & 1.538 & 0.532 \\
\hline$\Delta \rho_{\min }$ e $\AA^{-3}$ & -0.450 & -3.311 & -0.571 \\
\hline
\end{tabular}

\subsection{MTT Cytotoxicity Assay}

The antitumor activity against carcinoma cells was assayed by the MTT method [69]. Cells were seeded in 96-well plate at a density of $5 \times 10^{4}$ cells per well in a volume of $200 \mathrm{~mL}$ and were treated with various concentrations of the compounds for $24 \mathrm{~h}$. After treatment, $20 \mu \mathrm{L}$ of $5 \mathrm{mg} / \mathrm{mL}$ MTT (Sigma-Alrich, St. Louis, MO, US) was added to each treated cells and further incubated for $4 \mathrm{~h}$ at 37 ${ }^{\circ} \mathrm{C}$. Subsequently the medium was discarded from each well before adding $200 \mu \mathrm{L}$ DMSO (Fisher Scientific, Loughborough, UK). For complete dissolution, the plate was incubated for 15 min followed with gentle shaking for $5 \mathrm{~min}$. The cytotoxic effect of the organotins on HCT116 cells was assessed by measuring the absorbance of each well at $570 \mathrm{~nm}$. Mean absorbance for each concentration was expressed as a percentage of vehicle control absorbance and plotted versus compound concentration.

\section{Conclusions}

In this work, we have successfully synthesized a novel ligand and its three diorganotin(IV) hydroxamates, which gave fairly sharp melting points indicating that the compounds were pure and were characterized by elemental analyses, IR, NMR and X-ray single-crystal diffraction. The structural analyses of complexes 1-3 reveal that the coordination mode observed in metal-hydroxamic acid complexes is the $O, O$-bidentate chelation and a five membered chelated ring was assembled. The NMR and X-ray studies were in full concurrent with the IR spectral evidences. The crystal structures of the three diorganotin complexes adopted a six coordination geometry at tin which is coordinated to 
the carbonyl oxygen and hydroxyl oxygen of two benzohydroxamic acid ligands and the two organic substituent of the diorganotin(IV) fragment. The diphenyltin(IV) and triphenyltin(IV) complexes demonstrated promising antiproliferative activities whereas dimethyltin(IV) shows very little cytotoxic effect at $\mu \mathrm{M}$ concentration on human HCT116 cells.

\section{Supplementary Materials}

Supplementary materials can be accessed at: http://www.mdpi.com/1420-3049/18/7/8696/s1.

\section{Acknowledgments}

This work was supported by grant UKM-ST-06-FRGS 112-2009, UKM-GUP-NBT-08-27-112, GUP-2012-022 and UKM-GGPM-TKP-052-2010 and we gratefully acknowledge the School of Chemical Sciences and Food Technology, Universiti Kebangsaan Malaysia, for providing the essential laboratory facilities. We would also like to thank the Faculty Development Programme, University of Balochistan Quetta, Pakistan for their financial support.

\section{Conflict of Interest}

The authors declare no conflict of interest.

\section{References}

1. Nandurkar, N.S.; Petersen, R.; Qvortrup, K.; Komnatnyy, V.V.; Taveras, K.M.; Le Quement, S.T.; Frauenlob, R.; Givskov, M.; Nielsena, T.E. A convenient procedure for the solid-phase synthesis of hydroxamic acids on PEGA resins. Tetrahedron Lett. 2011, 52, 7121-7124.

2. Farkas, E.; Csoka, H.; Gama, S.; Santos, M.A. Dihydroxamate based siderophore model, piperazine-1,4-bis-(N-methyl-acetohydroxamic acid (PIPDMAHA), as a chelating agent of molybdenum(VI). Talanta 2002, 57, 935-943.

3. Jain, R.; Sundram, A.; Lopez, S.; Neckermann, G.; Wu, C.; Hackbarth, C.; Chen, D.; Wang, W.; Ryder, NS.; Weidmann, B.; et al. $\alpha$-Substituted hydroxamic acids as novel bacterial deformylase inhibitor-based antibacterial agents. Bioorg. Med. Chem. Lett. 2003, 13, 4223-4228.

4. Farkas, E.; Enyedy, E.A.; Micera, G.; Garribba, E. Coordination modes of hydroxamic acids in copper(II), nickel(II) and zinc(II) mixed-ligand complexes in aqueous solution. Polyhedron 2000, 19, 1727-1736.

5. Sibi, M.P.; Hasegawa, H.; Ghorpade, S.R. A Convenient Method for the Conversion of $\mathrm{N}$-Acyloxazolidinones to Hydroxamic Acids. Org. Lett. 2002, 4, 3343-3346.

6. Giacomelli G.; Porcheddu, A.; Salaris, M. Simple One-Flask Method for the Preparation of Hydroxamic Acids. Org. Lett. 2003, 5, 2715-2717.

7. Porcheddu. A.; Giacomelli, G. Angeli-Rimini's Reaction on solid support: A new approach to hydroxamic acids. J. Org. Chem. 2006, 71, 7057-7059.

8. Reddy, A.S.; Kumar, M.S.; Reddy. G.R. A convenient method for the preparation of hydroxamic acids. Tetrahedron Lett. 2000, 41, 6285-6288. 
9. Volonterio, A.; Bellosta, A.S.; Bravo, P.; Canavesi, M.; Corradi, E.; Meille, S.V.; Monetti, M.; Moussier, N.; Zanda, M. Solution/Solid-Phase synthesis of partially modified Retro- and Retro-Inverso- $\psi\left[\mathrm{NHCH}\left(\mathrm{CF}_{3}\right)\right]-$ Peptidyl hydroxamates and their evaluation as MMP-9 inhibitors, Eur. J. Org. Chem. 2002, 2002, 428-438.

10. Price, S.; Osbourn, S.E. Solid-Phase Synthesis of $N$-Formylhydroxylamines (Reverse/Retro Hydroxamates). Org. Lett. 2005, 7, 3761-3763.

11. Codd, R. Traversing the coordination chemistry and chemical biology of hydroxamic acids. Coord. Chem. Rev. 2008, 252, 1387-1408.

12. Mishra, H.; Parrill, A.L.; Williamsom, J.S. Three-dimensional quantitative structure-activity relationship and comparative molecular field analysis of dipeptide hydroxamic acid. Antimicrob. Agents Chemother. 2002, 46, 2613-2618.

13. Zhang, Y.; Li, D.; Houtman, J.C.; Witiak, D.T.; Seltzer, J.; Bertics, P.J.; Lauhon, C.T. Design, combinatorial chemical synthesis and in vitro characterization of novel urea based gelatinase inhibitors. Bioorg. Med. Chem. Lett. 1999, 9, 2823-2826.

14. Tsukamoto, K.; Itakura, H.; Sato, K.; Fukuyama, K.; Miura, S.; Takahashi, S.; Ikezawa, H.; Hosoya, T. Binding of salicylhydroxamic acid and several aromatic donor molecules to Arthromyces ramosus peroxidase, investigated by X-ray crystallography, Optical difference spectroscopy, NMR relaxation, molecular dynamics, and kinetics. Biochemistry 1999, 38, 12558-12568.

15. Leung, D.; Abbenante, G.; Fairlie, D.P. Protease inhibitors: current status and future prospects. J. Med. Chem. 2000, 43, 305-341.

16. Hidalgo, M.; Eckhardt, S.G. Development of matrix metalloproteinase inhibitors in cancer Therapy. J. Natl. Cancer Inst. 2001, 93, 178-193.

17. Albrecht-Gary, A.M.; Libman, J.; Shanzer, A. Biomimetic iron(111) trishydroxamate complexes and triple stranded diferric helices. Pure Appl. Chem. 1996, 68, 1243-1247.

18. Hara, Y.; Shen, L.; Tsubouchi, A.; Akiyama, M.; Umemoto, K. Tripodal peptide hydroxamates as siderophore models. iron(III) binding with ligands containing H-(Alanyl $)_{n}-\beta$-( $N$-hydroxy)alanyl strands ( $n=1-3)$ anchored by nitrilotriacetic acid. Inorg. Chem. 2000, 39, 5074-5082.

19. Munster, P.N.; Troso-Sandoval, T.; Rosen, N.; Rifkind, R.; Marks, P.A.; Richon, V.M. The histone deacetylase inhibitor suberoylanilide hydroxamic acid induces differentiation of human breast cancer cells. Cancer Res. 2001, 61, 8492-8497.

20. Steward, W.P.; Thomas, A.L. Marimastat: the clinical development of a matrix metallopro-teinase inhibitor. Expert Opin. Invest. Drugs 2000, 9, 2913-2922.

21. Jeng, A.Y.; De Lombaert, S. Endothelin converting enzyme inhibitors. Curr. Pharm. Des. 1997, 3, 597-614.

22. Torres, G. Hydroxyurea, a potential new anti-HIV agent. GMHC Treatment Issues 1995, 9, 7-9.

23. Parvathy, S.; Hussain, I.; Karran, E.H.; Turner, A.J.; Hooper, N.M. Alzheimer's Amyloid Precursor Protein $\alpha$-Secretase Is Inhibited by Hydroxamic Acid-Based Zinc Metalloprotease Inhibitors: Similarities to the Angiotensin Converting Enzyme Secretase. Biochem. 1998, 37, 1680-1685.

24. Cabantchik, Z.I. Iron Chelators as antimalarials: the biochemical basis of selective cytotoxicity. Parasitol. Today 1995, 11, 74-78. 
25. Tsafack, A.; Golenser, J.; Libman, J.; Shanzer, A.; Cabantchik, Z.I. Mode of action of iron(III) chelators as antimalarials. III. Over additive effects in the combined action of hydroxamate-based agents on in vitro growth of Plasmodium falciparum. Mol. Pharmacol. 1995, 47, 403-409.

26. Valapour, M.; Gou, J.; Schroeder, J.T.; Keen, J.; Cianferoni, A.; Casolaro, V.; Georas, S.N. Histone deacetylation inhibits IL-4 gene expression in T cells. J. Allergy Clin. Immunol. 2002, $109,238-245$.

27. Drovetskaia, T.V.; Yashina, N.S.; Leonova, T.V.; Petrosyan, V.S.; Lorberth, J.; Wocadlo, S.; Massa, W.; Pebler, J. Synthesis and structure of some Diethyl and Diphenyltin Bis-Hydroxamates. J. Organomet. Chem. 1996, 507, 201-205.

28. Smith, F.E.; Khoo, L.E.; Goh, N.K.; Hynes, R.C.; Eng, G. The synthesis, and molecular and crystal structure of diphenyl(2-oxidonaphthylmethyl-iminoacetato)tin(lV).Can. J. Chem. 1996, 74, 2041-2047.

29. Pellerito, L.; Nagy, L. Organotin(IV) complexes formed with biologically active ligands: Equilibrium and structural studies and some biological aspects. Chem. Rev. 2002, 224, 111-150.

30. Gielen, M. Organotin compounds and their therapeutic potential: a report from the Organo-metallic Chemistry Department of the Free University of Brussels. Appl. Organomet. Chem. 2002, 16, 481-494.

31. Nath, M.; Pokharia, S.; Yadav, R. Organotin(IV) complexes of amino acids and peptides, Coord. Chem. Rev. 2001, 215, 99-149.

32. Petrosyan, V.S.; Yashina, N.S.; Ponomarev, S.V. Syntheses, Structures and biological activites of Organogermaniun and Organotin derivatives of hydroxamic acids. Met. Based Drugs 1998, 5, 237-244.

33. Shang, X.M.; Wu, J.Z.; Li, Q.S. New Coordination Modes of Substituted Benzohydroxa-mic Acid with Dialkyltin(IV): Structural diversity through Ligand Isomerization. Eur. J. Inorg. Chem. 2006, 2006, 4143-4150.

34. Harrison, P.G.; King, T.J.; Phillips, R.C. Structural studies in main-group chemistry. Part XVI. Crystal and molecular structures of bis( $N$-acetylhydroxylamino)dimethyltin(IV) and its monohydrate. J. Chem. Soc. Dalton Trans. 1976, 22, 2317-2321.

35. Omae, I. Organotin antifouling paints and their alternatives. App. Organomet. Chem. 2003, 17, 81-105.

36. Otera, J. Transesterification. Chem. Rev. 1993, 93, 1449-1470.

37. Jensen, K.G.; Andersen, O.; Ronne, M. Organotin compounds induce aneuploidy in human peripheral lymphocytes in vitro. Mutat. Res. 1999, 246, 109-112.

38. Choa, J.S.; Wei, L.Y.; Huang, M.C.; Liang, S.C.; Chen, H.H.C. Genotoxic effects of triphenyltin acetate and triphenyltin hydroxide on mammalian cells in vitro and in vivo. Mutat. Res. 1999, 444, 167-174.

39. White, J.S.; Tobin, J.M.; Cooney, J.J. Organotin compounds and their interactions with microorganisms. Can. J. Microbiol. 1999, 45, 541-554.

40. Wong, P.T.S.; Chau, Y.K.; Kramar, O.; Bengert, G.A. Structure-toxicity relationship of tin compounds on Algae. Can. J. Fish. Aquat. Sci. 1982, 39, 483-488.

41. Berg, M.; Arnold, C.G.; Muller, S.R.; Muhlemann, J.; Schwarzenbach, R.P. Sorption and desorption behavior of organotin compounds in sediment-pore water systems. Environ. Sci. Technol. 2001, 35, 3151-3157. 
42. Gielen, M. Tin-Based Antitumour Drugs. Coord. Chem. Rev. 1996, 151, 41-51.

43. Gielen, M.; Biesemans, M.; Willem, R. Organotin compounds: from kinetics to stereo-chemistry and antitumour activities. Appl. Organomet. Chem. 2005, 19, 440-450.

44. Baul, T.; Masharing, C.; Ruisi, G.; Jirasko, R.; Holcapek, M.; De Vos, D.; Wolstenholme, D.; Linden, A. Self-assembly of extended Schiff base amino acetate keletons,2-\{[(2Z)-(3-hydroxy-1Methyl-2-butenylidene)]amino $\}$ Phenylpropio-nate and 2-\{[(E)-1-(2-hydroxy-aryl) alkylidene] amino\} Phenyl-propionate skeletons incorporating organotin(IV) moieties: Synthesis, spectroscopic characterization, crystal structures, and in vitro cytotoxic activity. J. Organomet. Chem. 2007, 692, 4849-4862.

45. Saad, E.; Farina, Y.; Baba, I.; Othman, H. Synthesis and characterization of some diorganotin(IV) bis( $N$-methyl $o$-nitrobenzohydroxamate). Sains Malays. 2003, 32, 79-86.

46. Shahid, S.; Ali, S.; Hussain, M.; Mazhar, M.; Mahmood, S.; Rehman, S. Synthesis, characterization and thermal analysis of organotin(IV) derivatives of 4-(N-Maleoyl) butanoate. Turk. J. Chem. 2002, 26, 589-597.

47. Li, Q.S.; Guedes da Silva, M.F.C.; Zhao J.H.; Pombeiro, A.J.L. Diorganotin(IV) derivatives of arylhydroxamic acids: Synthesis, Properties and antitumor activity. J. Organomet. Chem. 2004, 689, 4584-4591.

48. Lockhart, T.P.; Manders, W.F. Structural determination by NMR spectroscopy. Dependence of [2J(119Sn,1H)] on the Me-Sn-Me angle in methyltin (IV) compounds. Inorg. Chem. 1986, 25, 892-895.

49. Nadvornik, M.; Holeček, J.; Handlir, K.; Lycka, A. The [13]C and [119]Sn NMR spectra of Some four- and five-coordinate tri-n-butyltin (IV) compounds. J. Organomet. Chem. 1984, 275, 43-51.

50. Mohammad, M.; Khadija, S.; Sohail, M.; Saqib, A.; Moazzam, B. Synthesis, Spectral Characterization and Biological Applications of Tri- and Diorganotin(IV) Derivatives of 2[N-(2,6- Dichloro-3-methyl phenyl)amino]benzoic acid. Turk. J. Chem. 2004, 28, 17-26.

51. Das, M.K.; Nath, M.; Zuckermann, J.J. Di- And Triorganotin (IV) Derivatives of N, N-Substituted hydroxylamines. Inorg. Chem. Acta 1983, 71, 49-59.

52. Ahmed, F.; Ali, S.; Parvez, M.; Munir, A.; Mazhar, M.; Shah, T.A. Synthesis, Characterization and biological studies of tri- and diorganotin (IV) complexes with 2,4-difluoro-4-hydroxy-[1,1]biphenyle-3-carbolic acid: Crystal structure of $\left[\left(\mathrm{CH}_{3}\right)_{3} \mathrm{Sn}\left(\mathrm{C}_{13} \mathrm{H}_{7} \mathrm{O}_{3} \mathrm{~F}_{2}\right)\right]$. Heteroatom. Chem. 2002, 13, 638-642.

53. Ali, S.; Ahmad, F.; Mazhar, M.; Munir, A.; Masood, M.T. Synthesis and spectral studies of di- and triorganotin (IV) complexes with 2-(6-methoxynaphthyl) propionic acid (Naproxen). Synth. React. Inorg. Met-Org. Chem. 2001, 32, 357-372.

54. Yoder, C.H.; Margolis, L.A.; Horne, J.M. A Tin-119 NMR investigation of phosphine and phosphine oxide adducts of organotin chlorides. J. Organomet. Chem. 2001, 633, 33-38.

55. Holecek, J.; Nadvornik, M.; Handlír, K.; Lycka, A. ${ }^{13} \mathrm{C}$ and ${ }^{119} \mathrm{Sn}$ NMR spectra of di-n-butyltin(IV) compounds. J. Organomet. Chem. 1986, 315, 299-308.

56. Choudhary, M.A.; Mazhar, M.; Ali, S.; Song, X.; Eng, G. Synthesis, characterization and biological activity of dimethyltin dicarboxylates containing germanium. Met. Based Drugs 2002, $8,275-281$. 
57. Harrison, P.G. Chemistry of Tin; Harrison, P.G, Ed.; Chapman and Hall: New York, NY, USA, 1989; p.76 and references therein.

58. Nath, M.; Yadav, R.; Gielen, M.; Dalil, H.; de Vos, D.; Eng, G. Synthesis, Characteristic spectral studies and in vitro antimicrobial and antitumour activities of organotin (IV) complexes of Schiff bases derived from amino acids. App. Organomet. Chem. 1997, 11, 727-736.

59. Harrison, P.G.; King, T.J.; Richards, J.A. Structural studies in main group chemistry. Part VIII. The crystal and molecular structure of $\operatorname{Bis}(N$-methyl acetylhydroxylamino) dimethyltin(IV). J. Chem. Soc. Dalton Trans. 1975, 9, 826-830.

60. Shang, X.M.; Li, Q.S.; Wu, J.Z. Synthesis and crystal structure of a mixed-ligand compound di-n-butyl-(4-chlorobenzohydroxamato)tin(IV). J. Organomet. Chem. 2005, 17, 3997-4000.

61. Gomez-Ruiz, S.; Kaluderovic, G.N.; Prashar, S.; Hey-Hawkins, E.; Eric, A.; Zizak , Z.; Juranic, Z.D. Study of the cytotoxic activity of di and triphenyltin(IV) carboxylate complexes. J. Inorg. Biochem. 2008, 102, 2087-2096.

62. Gielen, M.; Handlir, K.; Hollein, M.; De Vos, D. Synthesis, characterization and anti-tumour activity of some butyltin (IV) cysteaminates and N,N-dimethyl-cysteaminates. Met. Based Drugs 2000, 7, 233-236.

63. Gielen, M.; Biesemans, M.; De Vos, D.; Willem, R. Synthesis, characterization and in vitro antitumor activity of di- and triorganotin derivatives of polyoxa- and biologically relevant carboxylic acids. J. Inorg. Biochem. 2000, 79, 139-145.

64. Xanthopoulou, M.N.; Hadjikakou, S.K.; Hadjiliadis, N.; Schurmann, M.; Jurkschat, K.; Michaelides, A.; Skoulika, S.; Bakas, T.; Binolis, J.; Karkabounas, S.; et al. Synthesis, Structural characterization and in vitro cytotoxicity of organotin(IV) derivatives of heterocyclic thioamides, 2-mercaptobenzothiazole, 5-chloro-2-mercaptobenzothiazole, 3-methyl-2-mercaptobenzothiazole and 2-mercaptonicotinic acid. J. Inorg. Biochem. 2003, 96, 425-434.

65. Sharma, N.; Puneet, P.; Sharma, V.; Bhatt S.S.; Chaudhary, S.C. Synthesis, characterization and thermal study of di- and triphenyltin(IV) complexes of $p$-chloro and p-nitro and benzohydroxamic acid. Synth. Reactiv. Inorg. Metal-Org. C 1997, 27, 1381-1397.

66. APEX2 and SAINT; Bruker AXS Inc.: Madison, WI, USA, 2008.

67. Sheldrick, G.M. A short history of SHELX. Acta Cryst. 2008, A64, 112-122.

68. Sheldrick, G.M. SHELXS-97, Program for Crystal Structure Determination; University of Göttingen: Göttingen, Germany, 1997.

69. Denizot, F.; Lang, R. Rapid colorimetric assay for cell growth and survival Modifications to the tetrazolium dye procedure giving improved sensitivity and reliability. J. Immunol. Meth. 1986, 89, 271-277.

Sample Availability: Samples of the ligand and complexes are available from the authors.

(C) 2013 by the authors; licensee MDPI, Basel, Switzerland. This article is an open access article distributed under the terms and conditions of the Creative Commons Attribution license (http://creativecommons.org/licenses/by/3.0/). 